ment and construction at grant-receiving institutions, a new programme that is being welcomed by the research and university groups that have lobbied for years for NIH to address the problem of crumbling infrastructure at US universities.

In a related matter, Congress decided at the last minute to abandon temporarily a bill that would have offered an alternative to the current administration ban on fetal tissue research and established or modified several other NIH programmes, including those on the health of minorities and women. "We ran out of time, not votes", says Maureen Burns of the Association of American Universities.

\section{National Aeronautics and Space Administration}

As with NIH, the 1993 NASA budget will be essentially flat. But space science was treated relatively well. Big research projects such as the Earth Observing System, the Advanced X-Ray Astrophysics Facility and the Cassini mission to Saturn received about as much as the agency had requested, and space science received altogether an increase of slightly more than 4 per cent. Given that the overall NASA budget represents no growth at all - even for inflation - something had to give to make up for space science's rise. The obvious targets were those furthest away: Congress eliminated funding in 1993 for the planned National Aerospace Plane and for missions to the Moon and Mars. Although that action does not kill the two projects, it reduces the chances of success in fiscal year 1994.

For researchers who use satellite data, perhaps the most significant action as Congress moved towards adjournment was a major reform of the Landsat remote-sensing programme (see Nature 359, 353; 1992). The legislation will return Landsat to the government, ensuring a much-needed seventh orbiter and lower prices.

\section{Department of Energy}

Research spending by the Department of Energy (DOE) will grow hardly at all from 1992 levels. Funding for most programmes rose at most by one or two per cent, and some categories, including both high-energy and nuclear physics, suffered cuts. But Congress did provide the necessary sums for several physics projects under construction, including the Continuous Electron Beam Accelerator Facility (CEBAF) in Newport News, Virginia, the Relativistic Heavy Ion Collider (RHIC) at Brookhaven National Laboratories, and the Advanced Photon Source (APS) at Argonne National Laboratory. However, the Argonne project may yet fall victim to mandatory reductions to be negotiated between DOE and Congress during the next month that would delay by almost a year the opening, now scheduled for spring 1995, of some of its beam lines.

\title{
Human Frontiers looks for leader in Europe; US wavers
}

Tokyo \& Munich. In a complex contest of science and politics, three leading scientists from Europe are vying to take charge of the Strasbourg secretariat of the Japaneseinspired Human Frontier Science Program (HFSP), which supports international research on the brain and biological functions. The situation will be further complicated if
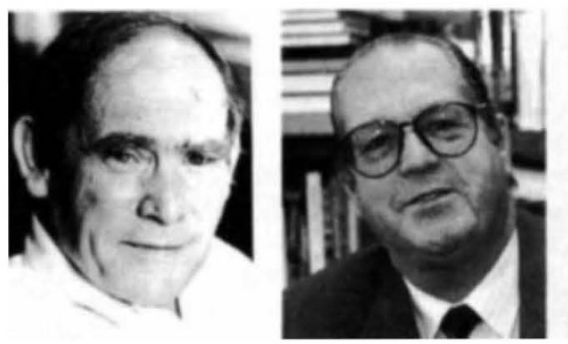

Sidney Brenner, Horst Sund and Michel Cuenod

the United States decides to nominate its own candidate.

The present secretary general, Sir James Gowans of Britain, will step down next spring following differences of opinion with Japanese and some European organizers of the programme over its direction (see $\mathrm{Na}$ ture 358, 527, 1992). So far, the three candidates for secretary general are Sydney Brenner, formerly at the Medical Research Centre and now at the University of Cambridge School of Medicine; Horst Sund of the University of Konstanz, Germany; and Michel Cuenod, director of the Brain Research Institute at the University of Zurich.

Any of the members of the programme (made up of Japan, the United States, Canada, the United Kingdom, France, Germany, Italy, Switzerland and the European Communi- ties) may nominate a candidate. Although the official deadline for nominations was 15 September, Japanese government officials have indicated that late entrees will be accepted. The US candidate is Lawrence Bogorad of Harvard University. Bogorad has refused to comment, but knowledgeable sources in Washington confirm that his name is likely to be submitted once bureaucratic hurdles are cleared, perhaps as early as this week.

In an odd twist, Sydney Brenner was nominated not by Britain but by Italy. The United Kingdom did not nominate a candidate because of its displeasure with the treatment given to Gowans, whose name was put forward at the urging of Japan when the Frontiers organization was established in 1989. Japan did not nominate anyone to avoid appearing to dominate the programme.

The choice of secretary general will be made in Strasbourg next month by the HFSP board of trustees after the nominees have been screened by the HFSP council of scientists. The trustees must decide the extent to which he must be an expert in the fields supported by the programme and whether he should be a day-to-day administrator or more of an intellectual leader. Politics will also play a part: one country has already hinted that it will give more money to HFSP if its candidate is chosen. Japan now provides most of the funds for the nearly $\$ 40$ million programme.

David Swinbanks \& Alison Abbott

\section{User fees to hasten FDA review}

Washington. Drug companies will begin paying a fee to help the US Food and Drug Administration (FDA) to review new drug applications more quickly under legislation approved last week in the waning days of the 102nd Congress. With the FDA's budget increasing by only 2.6 per cent this year, forcing companies to shoulder some of the financial burden is the only way that FDA can keep pace with its increasing workload, particularly in biotechnology.

The idea of charging users is not new: earlier this year, for example, the administration proposed raising $\$ 200$ million of the agency's \$791-million budget with such fees. The drug industry has traditionally opposed the idea, calling it a tax on innovation that would be particularly burdensome to new, small companies. But it acquiesced after Congress and the FDA agreed that the revenue would supplement - not replace - the agency's regular appropriation.

User fees are expected to bring in about $\$ 330$ million during the next five years, allowing the FDA to eliminate its backlog of new drug applications within two years and to shorten the average time of review from 24 to 12 months. To do this, the FDA would hire 600 new reviewers.

The bill takes into account the precarious financial status of small companies by permitting those with fewer than 500 employees and without products on the market to pay only half of the $\$ 100,000$ fee for a new drug application and to defer payment for one year.

Diane Gershon 